\title{
Assessment of Undiscovered Oil and Gas Resources of the Taoudeni Basin Province, Mali and Mauritania, 2015
}

Using a geology-based assessment methodology, the U.S. Geological Survey estimated undiscovered, technically recoverable mean resources of 160 million barrels of conventional oil, 1,880 billion cubic feet of conventional gas, 602 million barrels of shale oil, and 6,395 billion cubic feet of shale gas in the Taoudeni Basin Province in Mali and Mauritania.

\section{Introduction}

The objective of the U.S. Geological Survey (USGS) National and Global Petroleum Assessments project is to assess the potential for undiscovered, technically recoverable oil and gas resources within priority geologic provinces around the world. As part of this project, the USGS completed an assessment of the conventional and unconventional (continuous) oil and gas resources of the Taoudeni Basin Province (fig. 1), a complex province encompassing an area of approximately 1.9 million square kilometers, largely within Mali and Mauritania (Villeneuve, 2005). As much as 6 kilometers of infra-Cambrian sedimentary rocks (defined here to include sedimentary rocks of Neoproterozoic and Early Cambrian age) and other Paleozoic sedimentary rocks are present in the Taoudeni Basin Province (Waters and Schofield, 2004). It contains five oil and gas exploration wells (fig. 1) drilled between 1973 and 2011 (IHS Energy, 2014). With this level of exploration, the Taoudeni Basin Province is considered to be a frontier province (underexplored).

\section{Total Petroleum Systems and Assessment Units}

The assessment of conventional oil and gas resources relies on defining and evaluating potential total petroleum systems (TPS) and the geologic elements within the TPS. Geologic elements include petroleum source rocks (source rock maturation, petroleum generation and migration), reservoir rocks (quality and distribution), and traps for petroleum accumulations. For the Taoudeni Basin Province, the USGS defined an Infra-Cambrian Composite TPS and an Infra-Cambrian Reservoirs Assessment Unit (AU) to include infra-Cambrian source rocks and conventional reservoirs. The Silurian-Devonian Composite TPS includes a Lower Paleozoic

Reservoirs AU and is defined by Silurian and minor Devonian source rocks and Paleozoic conventional reservoirs. Petroleum shows and limited well-test data for the five exploration wells in the province provide some evidence that these petroleum systems exist. For example, the Abolag 1 well, located in the

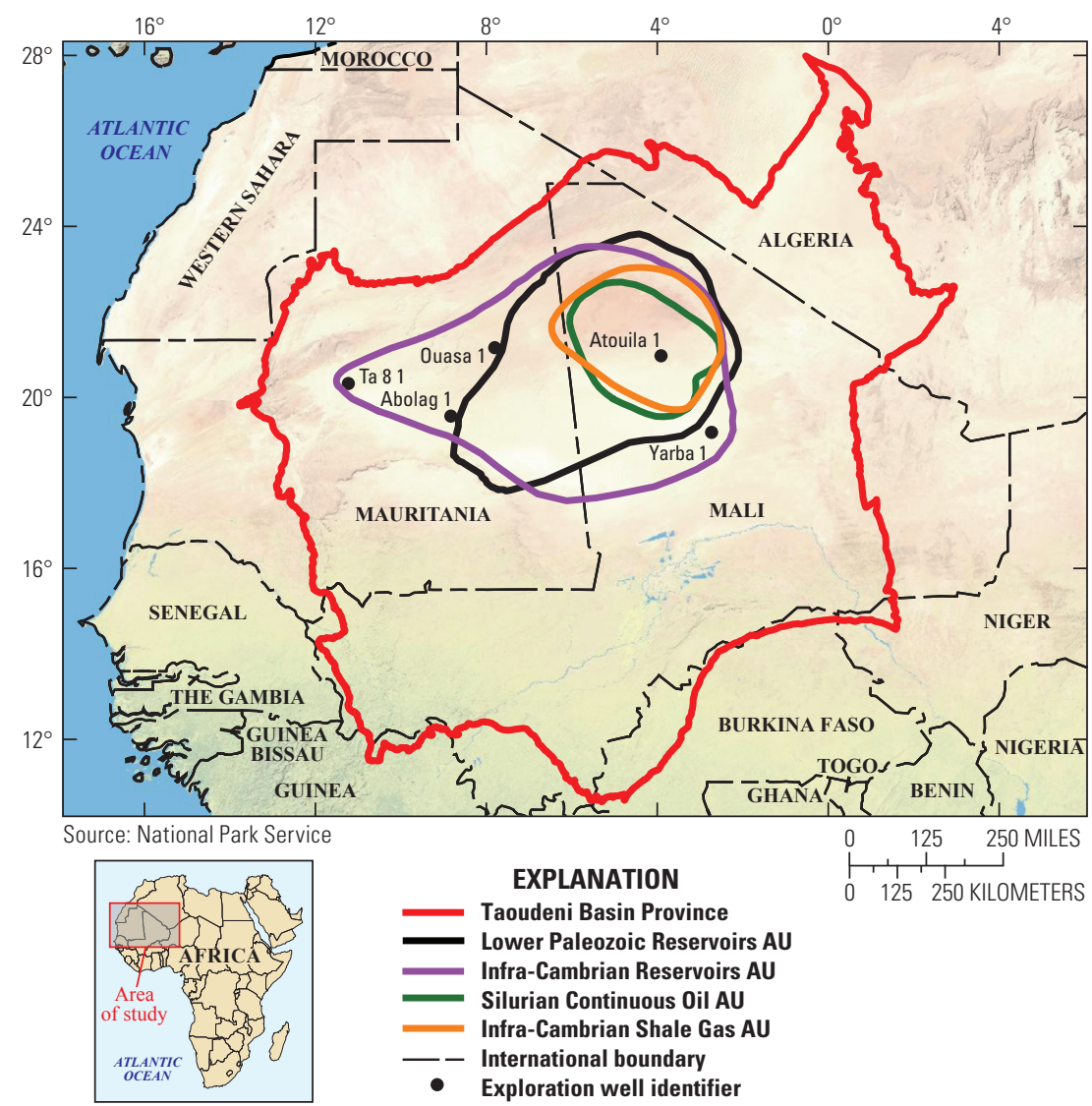

Figure 1. Location of the Taoudeni Basin Province and the four assessment units defined in this study. AU, assessment unit.

southwestern part of the basin, yielded 0.48 million cubic feet of gas per day in 1974 that was reportedly recovered from an infra-Cambrian carbonate reservoir (fig. 1; Wenzhe, 2009). Assessment input data for each assessment unit are shown in table 1.

The assessment of continuous oil and gas resources by the USGS requires that the potential sourcereservoir system must (1) have total organic carbon contents greater than 2 weight percent, (2) contain Type I or Type II organic matter, (3) be within the oil and gas thermal maturity generation window, (4) have organicrich shale greater than 15 meters in thickness, and (5) generally occur at depths greater than 1,500 meters (Charpentier and Cook, 2011). Using these parameters, the USGS defined an Infra-Cambrian Shale Gas AU within the Infra-Cambrian Composite TPS and a Silurian Continuous Oil AU within the Silurian-Devonian Composite TPS (fig. 1). Assessment input data for each assessment unit are shown in table 1 .

Petroleum generation from infra-Cambrian source rocks is interpreted to have begun in the Cambrian 
and continued into the Carboniferous prior to the Hercynian orogeny (Wenzhe, 2009). Petroleum generation from Silurian source rocks possibly began in the late Silurian and continued into the Carboniferous (Wenzhe, 2009). Generation ended with the Hercynian orogeny; uplift and erosion during this orogeny removed at least 2,400 meters of sediment from the central part of the basin, possibly influencing the retention of petroleum in conventional traps or in source rocks.

\section{Undiscovered Resource Summary}

The USGS quantitatively assessed undiscovered oil and gas resources within two conventional assessment units and two unconventional (continuous) assessment units within the Taoudeni Basin Province (table 2). For conventional resources, the estimated mean totals for the Lower Paleozoic Reservoirs AU are 160 million barrels of oil (MMBO), 99 billion cubic feet of gas (BCFG), and 2 million barrels of natural gas liquids (MMBNGL). Estimated mean totals for the Infra-Cambrian Reservoirs AU are 1,781 BCFG and 82 MMBNGL. For continuous resources, the estimated mean totals for the Silurian Continuous Oil AU are $602 \mathrm{MMBO}$, $361 \mathrm{BCFG}$, and 6 MMBNGL; the estimated mean totals for the Infra-Cambrian Shale Gas AU are 6,034 BCFG and 218 MMBNGL. The major source of geologic risk for continuous resources within the Taoudeni Basin Province is the retention of some part of oil or gas within the source rock following any phases of migration.

Table 1. Key assessment input data for the four assessment units of the Taoudeni Basin Province.

[AU, assessment unit; \%, percent; EUR, estimated ultimate recovery per well; MMBO, million barrels of oil; BCFG, billion cubic feet of gas; MMBNGL, million

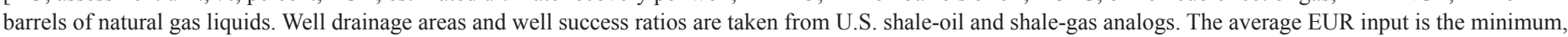
median, maximum, and calculated mean. Shading indicates not applicable]

\begin{tabular}{|c|c|c|c|c|c|c|c|c|}
\hline \multirow{2}{*}{ Assessment input data-Continuous AU } & \multicolumn{4}{|c|}{ Silurian Continuous Oil AU } & \multicolumn{4}{|c|}{ Infra-Cambrian Shale Gas AU } \\
\hline & Minimum & Mode & Maximum & Calculated mean & Minimum & Mode & Maximum & Calculated mean \\
\hline Potential production area of AU (acres) & 21,500 & $10,500,000$ & $21,500,000$ & $10,673,833$ & 25,960 & $13,000,000$ & $25,959,000$ & $12,994,987$ \\
\hline Average drainage area of wells (acres) & 120 & 160 & 200 & 160 & 120 & 160 & 200 & 160 \\
\hline Success ratios $(\%)$ & 5 & 40 & 80 & 41.7 & 10 & 40 & 80 & 43.3 \\
\hline Average EUR (MMBO, oil; BCFG, gas) & 0.01 & 0.02 & 0.1 & 0.024 & 0.1 & 0.15 & 1 & 0.194 \\
\hline AU probability & 0.9 & & & & 0.9 & & & \\
\hline Assessment input data-Conventional AU & \multicolumn{4}{|c|}{ Lower Paleozoic Reservoirs AU } & \multicolumn{4}{|c|}{ Infra-Cambrian Reservoirs AU } \\
\hline Number of oil fields & 1 & 25 & 150 & 29 & & & & \\
\hline Number of gas fields & & & & & 1 & 50 & 400 & 62 \\
\hline Sizes of oil fields (MMBO) & 1 & 3 & 150 & 5 & & & & \\
\hline Sizes of gas fields (BCFG) & & & & & 6 & 18 & 600 & 27 \\
\hline AU probability & 0.9 & & & & 0.9 & & & \\
\hline
\end{tabular}

Table 2. Assessment results for the Taoudeni Basin Province.

[AU, assessment unit; MMBO, million barrels of oil; BCFG, billions of cubic feet of gas; MMBNGL, million barrels of natural gas liquids. Results shown are fully risked estimates. For gas accumulations, all liquids are included under the NGL (natural gas liquids) category. F95 represents a 95 percent chance of at least the amount tabulated. Other fractiles are defined similarly. Fractiles are additive under assumption of perfect positive correlation. Shading indicates not applicable]

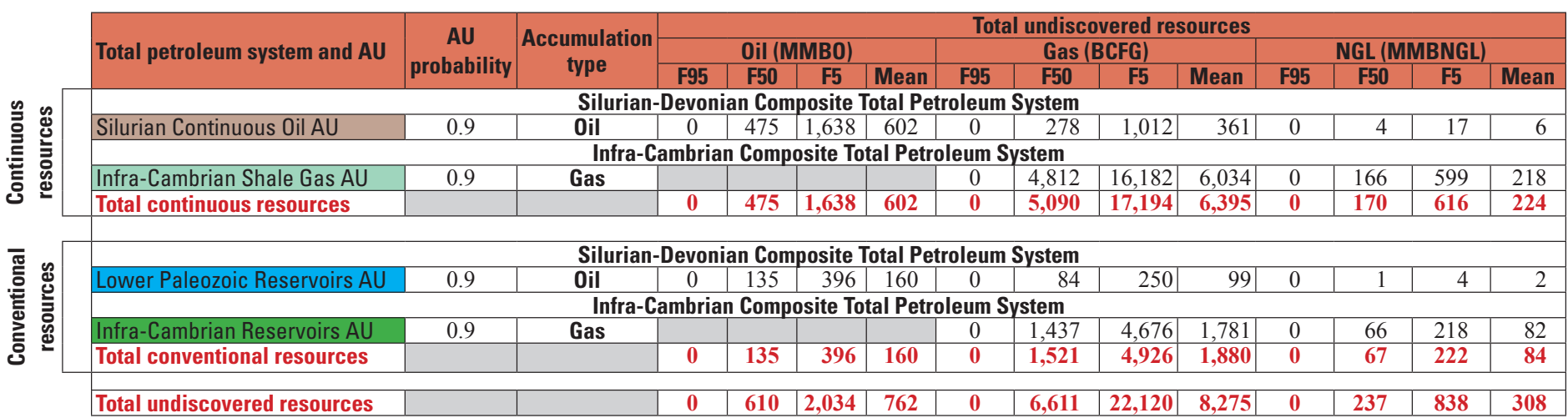

\section{References}

Charpentier, R.R., and Cook, T.A., 2011, USGS methodology for assessing continuous petroleum resources: U.S. Geological Survey Open-File Report 2011-1167, 75 p. [Also available at http://pubs.usgs.gov/of/2011/1167/.]

IHS Energy, 2014, International petroleum exploration and production database [current through December 2013]: IHS Energy. [Available from IHS Energy, 15 Inverness Way East, Englewood, CO 80112.]

Villeneuve, Michel, 2005, Paleozoic basins in West Africa and the Mauritanide thrust belt: Journal of African Earth Sciences, v. 43, nos. 1-3, p. 166-195.

Waters, C.N., and Schofield, D.I., 2004, Contrasting late Neoproterozoic to Ordovician successions of the Taoudeni Basin, Mauritania, and Souss Basin, Morocco: Journal of African Earth Sciences, v. 39, nos. 3-4, p. 301-309.

Wenzhe, Gang, 2009, Hydrocarbon generation conditions and exploration potential of the Taoudeni Basin, Mauritania: Petroleum Science, v. 6, p. 29-37.

\section{For Further Information}

Assessment results also are available at the USGS Energy Resources Program Web site at http://energy.usgs.gov.

\section{Taoudeni Basin Province Assessment Team}

Michael E. Brownfield, Christopher J. Schenk, Timothy R. Klett, Marilyn E. Tennyson, Janet K. Pitman, Stephanie B. Gaswirth, Phuong A. Le, Heidi M. Leathers-Miller, Tracey J. Mercier, Kristen R. Marra, and Sarah J. Hawkins 